\title{
SPONTANEOUS RUPTURE OF THE HEART
}

\author{
A Historical Review \\ Arnold Levene, M.B., F.R.C.S. \\ Assistant Pathologist, Royal Marsden Hospital, London, S.W.3
}

A RECENT paper by Crawford and Morris (Ig6o) shows that 5,000 deaths from rupture of the heart occur annually in Britain. The striking features which it presents at post-mortem-its recognition is inescapable to the most casual inspectionnaturally led to its description in pathological works long before coronary occlusion and myocardial infarction, its necessary antecedents, were defined. Two centuries elapsed between Harvey's description of a case and the interpretation of the basic pathological changes involved. In the further century that has passed, the pathological changes have been described with greater exactness, and certain clinical and epidemiological facts have been added. After a brief account of the condition it is the purpose of the present paper to consider some of the significant literature of the past.

\section{Incidence and Pathology}

Spontaneous rupture of the heart is found at autopsy to account for about $5 \%$ of deaths attributable to coronary artery disease and for $10 \%$ of that form which is associated with myocardial infarction. It occurs mainly in the winter, in elderly subjects, and is seen with equal frequency in men and women, unlike coronary disease as a whole, which shows a pronounced predilection for males. This is attributable to the later onset of coronary atheroma and incidence of myocardial infarction in women. The symptomatology and history of those cases proceeding to rupture does not differ from those fatal cases of myocardial infarction in which no rupture is found at autopsy. It is not proven that hypertension, present either before or after the episode of infarction, is a significant factor in precipitating rupture, the weight of morbid anatomical and clinical evidence being against this idea. During the period in which the treatment of myocardial infarcts by anticoagulants was being developed there was an increase in the incidence of hæmorrhagic pericardial effusions, but no convincing data of the increased incidence of myocardial rupture. Although there are a handful of cases recorded in which a physician has correctly $\overrightarrow{\vec{\omega}}$ diagnosed external rupture of the ventricle, death from cardiac tamponade must follow so rapidly on completion of the tear through the ventricular wall that the diagnosis can virtually be only made ${ }_{\infty}^{\omega}$ at autopsy. This is not the case with intracardiac ruptures which, being compatible with long-term 0 survival, are diagnosed and have on occasion beenw repaired. Flectrocardiographic and morbid ana- $\stackrel{\oplus}{\circ}$ tomical findings agree in the demonstration of $a^{\circ}$ transmural infarct in the majority of cases. Such $_{\vec{C}}$ infarcts show no special distribution in the myocardium though the actual rupture passes $(\mathbf{I})_{-}^{\Phi}$ through the junction of living and necrotic musctec $\vec{\varnothing}$ in the case of large infarcts, (2) through the ange? made by the junction of the left ventricle with theo interventricular septum in the case of ventriculaseptal infarcts, or (3) as a simple tear through the middle of the small infarct. Nearly all ruptures occur within the first week after infarction and are $\frac{2}{2}$ unknown in hearts which have recovered from $a \stackrel{2}{\Rightarrow}$ previous major episode of infarction with gross $\frac{3}{3}$ scarring, that is except for the rare rupture of cardiac aneurysm. The post-mortem appearances are briefly: (I) a hæmopericardium of half to three quarters of a pint which forms a cast about 3 . the heart and strips to leave a smooth, dulled or:roughened surface depending on the age of the infarct; (2) a bruised area of epicardium overlyingô an infarct and associated with which is a short slit a few millimetres to $4 \mathrm{~cm}$. in length lying in theo long axis of the heart (multiple exit tears are sometimes found); (3) a zig-zag tear through the myocardium with some tracking of the associated hæmatoma in the muscle layers; and (4) a variable relation to an infarct as outlined above.

Apart from external rupture of the left ventricle the incidence of which is known with some cer-? tainty, and rupture of the interventricular septum which is seen about once for every 40 or 50 cases of external rupture, the frequency with which the? other varieties of cardiac rupture occur is unknown.0 Krumbhaar and Crowell's series (1925) and Davenport's supplement to it (1928) dealt with material which was quite inadequately docu踀 
mented, and the figures of 8.1 for atrial and 10.7 for right ventricular expressed as a percentage of all cases of rupture do little more than reflect the incidence of these interesting conditions in the world literature. The possible anatomical variants of cardiac rupture and the different pathological changes which have been encountered have been classified by Benson, Hunter and Manlove (1933). In Great Britain, any cause other than myocardial infarction is a curiosity, as is any site other than the left ventricular wall (including the septum) in cases of cardiac rupture. Rupture of the right ventricle occurred in $9.26 \%$ of a series of right ventricular infarcts studied by Slapak (1956). Spontaneous rupture of the right ventricle due to fatty infiltration has been briefly reported (Howell, 1957), but the condition is so rare as to repay detailed study of fresh cases. Atrial ruptures were the subject of a review by Kohn, Harris and Gorman (1954).

\section{William Harvey's Case}

As may happen, the first recorded instance of a disease may not be a typical example of the condition. Here is Harvey's account of the case history and post-mortem findings in a subject dying of rupture of the left ventricle (Harvey, I649).

'A noble knight, Sir Robert Darcy, an ancestor of that celebrated physician and most learned man, my very dear friend Dr. Argent, when he had reached to about the middle period of life, made frequent complaint of a certain distressing pain in the chest, especially in the night season; so that dreading at one time syncope, at another suffocation in his attacks he led an unquiet and anxious life. He tried many remedies in vain, having had the advice of almost every medical man. The disease going from bad to worse, he by and by became cachectic and dropsical, and finally, grievously distressed, he died in one of his paroxysms. In the body of this gentleman, at the inspection of which there were present Dr. Argent, then president of the College of Physicians, and Dr. George, a distinguished theologian and preacher who was pastor of the parish, we found the wall of the left ventricle of the heart ruptured, having a rent in it of size sufficient to admit any of my fingers, although the wall itself appeared sufficiently thick and strong; this laceration had apparently been caused by an impediment to the passage of the blood from the left ventricle into the arteries'.

Two points in the above account demand comment. First, the history is of a middle-aged man subject to attacks of what could be left ventricular failure over a period of time, with terminal dropsy. This is a most unusual history were the case one of ruptured myocardial infarct, in which condition a history of heart disease is significantly absent. I have never observed œdema in such cases nor have others referred to it in connection with rupture of the heart. Secondly, does the last sentence imply that an obstruction which was found could have led to rupture, or does it merely express a surmise on Harvey's part that cardiac rupture was probably a manifestation of obstruction which was not found post-mortem? It is relevant here to recall that the hypertrophied heart resulting from chronic obstruction of the aortic valve never ruptures, a point supporting the latter interpretation as being the more likely.

\section{Later Reports}

Morgagni in 1769 reported II cases, and credited Harvey with the first account. In his 'Seats and Causes of Disease' there are several references to the condition. He was aware that it was a disease of old people with 'ossified' arteries, sometimes associated with softening of the ventricular wall, that the left ventricle was the site of rupture in most cases, and that it never occurred in a healthy heart. He stated that Morand had collected more cases and written more on the subject than anyone else, but I have been unable to trace the essays to which he referred. Morgagni thought that left ventricular ruptures were commoner than those in the thinner and weaker right ventricle because, firstly, the lower part of the left ventricle was thinner and weaker than the parieties of the right ventricle (in his cases 5 and 69 and, secondly, 'that in proportion the strength of the left ventricle was greater than that of the right? so much more forcible does it act upon its own parieties, especially when any obstacle opposes itself to the blood, which is coming out of the cavity'. Morgagni's book was published when he was 79 .

In the next hundred years, further understanding was impeded by the idea that myocardial infarction was a species of fatty degeneration. (Laennec (1926) opposed the contemporary belief that the pale areas in the myocardium were fatty in nature by pointing out that they did not grease paper.) The concept of ischæmic necrosis awaited the development of microscopy as an adjunct to pathological studies. Malmsten (1859) was the first to state clearly that he thought rupture of the heart was due to obstruction of a coronary artery. In $186 \mathrm{r}$, he reported a case of cardiac infarction and rupture. The autopsy was performed by $\mathrm{Mr}$. Duben.

'Microscopically the muscle fibres were here destroyed and replaced by highly granular detritus, here and there with fatty granules. In places there were small areas, visible even to the naked eye, where only connective tissue remained buried in the degenerated mass. The anterior branch of the left coronary artery contained an old white thrombus situated just before the entrance of the artery into the degenerated area. The clot was undoubtedly old. The 
arterial obstruction had resulted in a slow softening of the muscular tissues. Finally, rupture seems to have occurred slowly'.

His article was translated and appeared in the Dublin Medical Press.

Vulpian (1866) was undoubtedly the first to grasp the sequence of events: coronary thrombosis, myocardial infarction and softening and finally cardiac rupture. On January 24 , he presented a case to the Saltpêtrière Medical Society:

\begin{abstract}
'Ramollissment cérébrale ancien avec embarras de la paroi. Ramollissement cérébrale récent. Caillot ancien dans l'auricule gauche. Infarctus de la paroi du ventricule gauche du coeur coincident avec l'existence d'un caillot ancien dans l'une des artéres coronaires. Rupture de cet infarctus dans la cavité du péricarde. Hemorrhagie dans la cavité du péricarde'. In the discussion following on the presentation of the case he goes on as follows:

'Quoi qu'il en soit, le lésion de la paroi du coeur me parait avoir êté produite par l'oblitération de cette artére. Il y en a très vraisemblablement un infarctus qui se sera ramolli: et à un certain moment peut être dans les derniers instants de la vie, sous l'influence de fortes contractions du coeur, ces foyers, séparé par un couche tres mince de tissu musculaire de la cavité ventriculaire et de la surface externe se sera ouvert dans les deux points d'abord dans la cavité ventriculaire, puis sous l'effort du sang dans la cavité du péricarde et ainsi se sera fait l'hemorrhagie dans cette cavité'.
\end{abstract}

By the close of the Igth century, the various manifestations of occlusive atheromatous disease of the coronary arteries were well understood, leaving details to be thoroughly worked out, as for example, the topography of coronary occlusion and intercoronary anastomoses (Schlesinger, 1940) and the speed of healing of myocardial infarction (Mallory, White and Salcedo-Salgar, 1939) in this century. Rupture of the heart was the subject of a thesis by Elleaume (1857). He pointed out that the track of a left ventricular tear may be so oblique '. . . que l'orifice externe se trouve sur le coeur droit; ce qui pourait induire en erreur et faire croire a une rupture du coeur droit, si l'on se livrait a un examen attentif', and found that the endocardial situation of the tear is generally in the angle formed by the interventricular septum and the ventricular wall. Robin and Nicolle (1895) gave an excellent account of the morbid anatomy and histology of the condition.

\section{Recent Studies}

In a closely reasoned paper, Aubertin (1924) concluded (I) that the symptomatology of cardiac rupture is the symptomatology of coronary thrombosis, neither more nor less, and (2) that an early infarct ruptures, because there is an asso- 3 ciated hypertension. The first of his conclusions $\stackrel{\mathbb{Q}}{\complement}$ merely requires the qualification 'as it is seen in $ᄃ$ old age'. On the second, Edmondson and Hoxie $\overrightarrow{\vec{B}}$ (1942) found that patients with persistent hyper- $\frac{\text { ? }}{0}$ tension after infarction are three times more likely to develop rupture than those with normal $\frac{\bar{c}}{\bar{c}}$ or subnormal blood pressure; that hearts of $\overrightarrow{\mathbb{D}}$ normal weight in patients whose hypertension persists after infarction are most likely to rupture, $\infty$ and that hypertrophied hearts in patients with $\vec{\circ}$ normal or low blood pressure after infarction are least likely to rupture. Bean (1940), Lunseth and $\vec{\sigma}$ Ruwaldt (1956), Levene (1960) and Mitchell and Parish (1960) found no support for these views.

In a series of papers published between 1939 and 1948 Lowe produced detailed studies of the morbid 0 anatomical and mechanical factors in cardiac rup- $+\vec{f}$ ture. They form a most important and distinctive $\dot{\omega}_{\omega}$ contribution to the literature of the subject. They $\omega_{\oplus}^{\omega}$ have been briefly summarized (Levene, 1960) ando are incorporated in the introductory account of $\rightarrow$ cardiac rupture presented here. Kohn (1954) thought that rupture of an infarcted muscle is a statistical accident comparable to the fatigue frac- $\vec{\nabla}$ ture of metals. Paradoxical pulsation and normol systole combine to concentrate stress at the june-? tion of infarct with normal tissue in transmuna lesions. Once a rupture is started, by whatever mechanism, it will be completed by the pull of a normally contracting muscle, and possibly by dissection from a jet of blood. An intramural $\stackrel{\Phi}{\complement}$ hæmatoma, perhaps produced by anticoagulant $\overrightarrow{\vec{O}}$ therapy, may also be the source of this initial tear. 3 (This is the concept of apoplexie du coeur, of Elleaume and older writers.) What is left un-0. accounted for by Kohn is the peculiar age in-음 cidence of the condition. Is it merely a reflection of an increased incidence of transmural infarction $\frac{5}{3}$ in old age or alternatively of an alteration of the mechanical properties of senile myocardium or even a difference in the cellular and humoral responses to tissue injury? The other question to음 which no satisfactory explanation is available con- $\rightarrow$ cerns the role of anticoagulants in increasing the likelihood of rupture of myocardial infarction. N Were this significant, one might expect an increase in the incidence of rupture of the heart in the younger age groups or of the incidence of inter- $\omega$ ventricular septal ruptures, neither of which has been reported. 


\section{REFERENCES}

Aubertin, C. (1924): La Rupture du Coeur, Presse méd., 45, 485.

Benson, R. L., Hunter, W. C., and Manlove, C. H. (1933): Spontaneous Rupture of the Heart, Amer. F. Path., 9, 295.

Crawford, M. D., and Morris, J. N. (1960): Ruptured Ventricle Incidence in Population of London, 1957-58, Brit. med. F., ii, 1624 .

DAvenPoRT, A. B. (1928): Spontaneous Heart Rupture-A statistical summary, Amer. F. med. Sci., 176, 62.

EDmondson, H. A., and HoxIE, H. J. (1942): Hypertension and Cardiac Rupture. A clinical and pathological study of 72 cases in 13 of which rupture of the inter-ventricular septum occurred, Amer. Heart f., 24, 719.

Elleaume, A. H. (I857): Essai sur les Ruptures du Coeur. Thèse pour le doctorat en medicine, Paris.

HARVEY, W. (1649): 'The Works of William Harvey'. The Sydenham Society, London, 1847, p. 127.

HowELL, T. H. (1957): Rupture of the Right Ventricle-report of seven cases studied post-mortem, Geriatrics, 12,71 I.

KoHN, R. M. ( (959): Editorial, Amer. F. Cardiol., 4, 279. HarRis, R., and Gorman, L. W. (r954): Atrial Rupture of the Heart. Report of case following atrial infarction. Summary of 79 cases collected from literature, Circulation $(N . Y$.), 10, $22 \mathrm{I}$.

KrumbraAr, E. B., and Crowell, C. (1925): Spontaneous Rupture of the Heart. A clinico-pathological study based on 22 unpublished cases and 632 from the literature, Amer. F. med. Sci., 170, 828.

Laennec, R. T. H. (1926): The Present Status of Coronary Disease-quoted by Benson, R. L., Arch. Path. Lab. Med., 2,877 .

LEVENE, A. (r960): Spontaneous Rupture of the Heart, Brit. Heart F., 22, 660.

LowE, T. E. (1950): In 'Studies in Pathology Presented to Peter MacCallum', p. 8r. Melbourne University Press.

Lunseth, J. H., and RuwaldT, M. (1956): Pathogenesis of Cardiac Rupture due to Myocardial Infarction, a study of 26 cases, Dis. Chest, 30, 499.

Mallory, G. K., White, D. D., and Salcedo-Salgar, J. (1939): The Speed of Healing of Myocardial Infarction, Amer. Heart F., 18, 647.

Malmsten, P. H. (1859): Case Report, Hygeia (Stockh.), r, 629.

Mitchell, J. R. A., and PARISH, D. J. (1960): Rupture of the Heart, Lancet, ii, 1629.

MORGAGNI, J. B. (1769): 'The Seats and Causes of Disease', Letter 27, p. 830 . London.

Robin, A., and Nicolle, M. (I895): De la Rupture du Coeur, Paris.

Schlesinger, M. J. (1940): Relationship of Anatomic Pattern to Pathological Conditions of the Coronary Arteries, Arch. Path., 30, 403.

SLAPAK, L. (1956): Uber den Myocardinfarct im Bereich des rechten Ventrikels, Wein. Z. inn. Med., 37, 378.

Vulpian, E. F. (1866): Case Report, Un. méd. Prat. franf., 29, 417. 